\title{
Biostratigraphy and palaeoenvironmental interpretation of the Dalichai Formation (Lower Cretaceous) in the eastern and central Alborz Mountains (North Iran) based on calcareous nannofossils
}

\author{
Rana SHIRI ${ }^{1}$, Fatemeh HADAVI ${ }^{1, *}$ and Fereshteh SAJADI HAZAVEH ${ }^{2}$ \\ 1 Ferdowsi University of Mashhad, Department of Geology, Faculty of Sciences, Mashhad, Iran \\ 2 University of Tehran, Department of Geology, Faculty of Sciences, Tehran, Iran
}

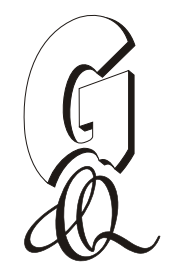

Shiri, R., Hadavi, F., Sajadi Hazaveh, F., 2020. Biostratigraphy and palaeoenvironmental interpretation of the Dalichai Formation (Lower Cretaceous) in the eastern and central Alborz Mountains (North Iran) based on calcareous nannofossils. Geological Quarterly, 64 (3): 641-657, doi: 10.7306/gq.1551

\begin{abstract}
Calcareous nannofossils are described from 4 sections of the Lower Cretaceous Dalichai Formation from the Eastern (Tepal, Talu and Lavan sections) and central Alborz Mountains (Yonjezar section), Iran. Forty-two species belonging to 18 genera have been identified from the 4 sections studied, including 13 species belonging to 8 genera of ascidian didemnids only from the Tepal section. These taxa indicate the CC1-CC5 biozones of Sissingh's (1977) biozonation and an age of Berriasian to Early Barremian. The nannofossils recorded from the Dalichai Formation are generally Tethyan and cosmopolitan, while the presence of some Boreal taxa (Nannoconus abundans and $N$. borealis) may reflect connection between the Boreal and Tethyan realms in the Early Barremian. The sedimentary basin of the Dalichai Formation of the Tepal, Talu, and Yonjezar sections was located at low latitudes of the Tethyan realm with warm surface water. Also, trends of increasing depth and productivity, of a shift from $r$-selected to k-selected strategies and of a change from low-to-high mesotrophic to oligotrophic conditions, were deduced. A change from unstable to stable conditions towards the tops of sections is inferred for these localities. Laterally in the Dalichai Basin from the eastern to central Alborz, there was an increase in depth and productivity, and also a trend towards oligotrophic conditions and a dominance of low-stress conditions.
\end{abstract}

Key words: biostratigraphy, palaeoecology, Dalichai Formation, boreal and Tethyan calcareous nannofossils, Iran, eastern and central Alborz.

\section{INTRODUCTION}

The Alborz is a large mountain range located in the north of Iran, stretching from the Iranian border in the west bank of the Caspian Sea, then forming a huge arc that traverses the south-west and south coasts of the Caspian Sea before joining the northern mountains of Khorasan province in the north-east of Iran (Jafari, 1989). The Alborz Mountains can be divided into three parts stratigraphically and tectonically: the western, central, and eastern Alborz (Jafari, 1989).

The Dalichai Formation that outcrops widely across the southern slopes of the Alborz is composed of marl and slightly sparry and thin-bedded marly limestone, with intercalations of marly shale in most places; it represents deposition in a marine environment that is markedly different from the lacustrine/lagoonal conditions recorded by the underlying strata (the Shemshak Formation) and the overlying thick-bedded carbonate deposits (Lar Formation; Aqhanabati, 2004).

\footnotetext{
* Corresponding author, e-mail: fhadavi@um.ac.ir

Received: December 11, 2019; accepted: March 23, 2020; first published online: August 21, 2020
}

Many studies focusing on ammonites (e.g., Majidifard, 2004; Vaziri et al., 2011; Seyed-Emami et al., 2018) and palynomorphs (e.g., Wheeler and Sarjeant, 1990; GhasemiNejad et al., 2012; Dehbozorgi et al., 2013, 2018; Mafi et al., 2014; Hashemi Yazdi et al., 2018) from this formation have indicated a Bajocian to Late Oxfordian age. But there are only a few studies on calcareous nannofossils from this formation (Hadavi et al., 2015; Barsan et al., 2016). Accordingly, this study was conducted to provide a detailed biostratigraphic and correlatory framework of the Dalichai Formation in 4 sections studied: 3 sections from the eastern (Tepal, Talu, and Lavan), and $1 \mathrm{sec}-$ tion from the central Alborz (Yonjezar) using calcareous nannofossils (Fig. 1 and Table 1).

\section{MATERIAL AND METHODS}

In all four sections, the lower boundary of the Dalichai Formation is disconformable on the Shemshak Formation stratigraphically, with red sandstone at the base, and its upper boundary is transitional to the Lar Formation (Figs. 2 and 3). Samples were taken at different stratigraphic levels from all lithologies. The samples were prepared using smear slide techniques (Bown and Young, 1998) and were examined under a light microscope (Olympus BX51) equipped with a gypsum 


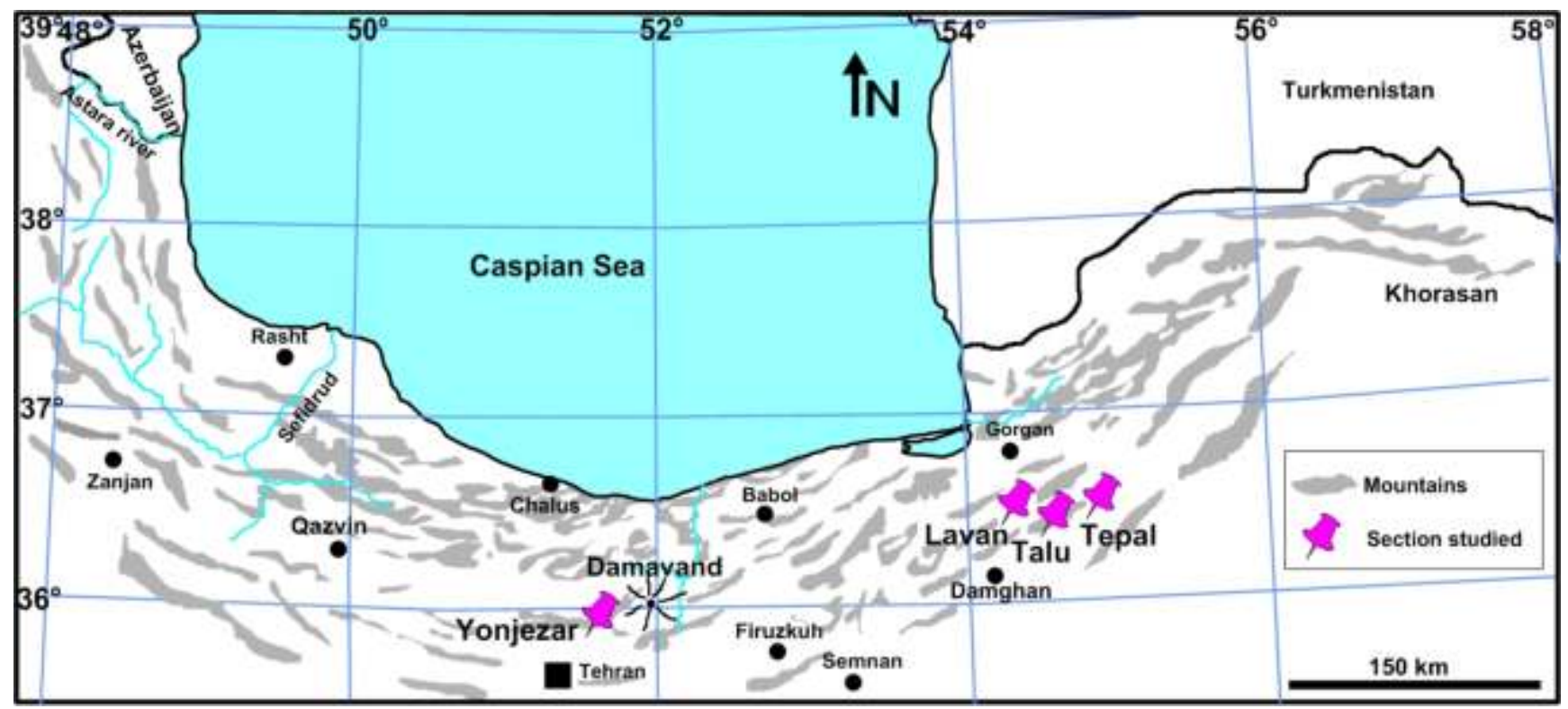

Fig. 1. Location of sections of the Dalichai Formation studied on a geological sketch map of the Alborz Mountains in the north of Iran (section studied)

Table 1

Characteristics of the sections studied

\begin{tabular}{|l|c|c|c|c|c|}
\hline Section name & Coordinate system & Position & Locality & $\begin{array}{c}\text { Thickness } \\
{[\mathrm{m}]}\end{array}$ & Numbers of samples \\
\hline Tepal & $36^{\circ} 22^{\prime} \mathrm{N} 54^{\circ} 44^{\prime} \mathrm{E}$ & eastern Alborz & west of Shahrud & 184 & 60 \\
\hline Talu & $36^{\circ} 19^{\prime} \mathrm{N} 54^{\circ} 26^{\prime} \mathrm{E}$ & eastern Alborz & north-east of Damghan & 153 & 64 \\
\hline Lavan & $36^{\circ} 22^{\prime} \mathrm{N} 54^{\circ} 14^{\prime} \mathrm{E}$ & eastern Alborz & north of Damghan & 182 & 57 \\
\hline Yonjezar & $35^{\circ} 59^{\prime} \mathrm{N} 51^{\circ} 42^{\prime} \mathrm{E}$ & central Alborz & north-east of Tehran & 210 & 51 \\
\hline
\end{tabular}

plate. Images of important nannofossils are illustrated in Figures 4-7. The biostratigraphic data obtained was interpreted using markers of Sissingh's (1977) biozonation. The relative abundances (\%) of the nannofossil species were counted, in 20 fields of view for some samples (Appendices 1-3*), and Figures 8-10 were drawn according to them.

\section{RESULTS}

In the present study, 42 species belonging to 18 genera of calcareous nannofossils were determined from the Tepal, Talu, Lavan and Yonjezar sections (Table 2). Due to the lack of abundant nannofossil assemblages and the very poor preservation of the specimens, nannofossils were not counted and shown for the Lavan Section.

Most of the nannofossils identified in these 4 sections are from two families, the Nannoconaceae and Watznaueriaceae. In addition, some ascidian spicules were recorded, though only in the Tepal Section. The most important species of the Nanno- conaceae in these 4 sections are as follows: Nannoconus abundans, $N$. borealis, N. bucheri, $N$. circularis, $N$. globulus subsp. globulus, $N$. kamptneri subsp. kamptneri, N. kamptneri subsp. minor, N. minutus, N. steinmannii subsp. steinmannii, and $N$. wassallii.

The dominant species of the Watznaueriaceae are as follows: Cyclagelosphaera argoensis, C. deflandrei, C. margerelii, Watznaueria barnesiae, W. biporta, W. britannica, W. cynthae, $W$. fossacincta, $W$. ovata, and $W$. rawsonii.

The other nannofossils determined are: Assipetra terebrodentarius, Broinsonia matalosa, Calcicalathina oblongata, Diadorhombus rectus, Discorhabdus ignotus, Lithraphidites bollii, $L$. carniolensis, Rhagodiscus asper, and $R$. robustus.

Ascidian spicules were observed at some intervals only of the Tepal Section. Species recognised were as follows: Acinodidemnum ecpalesis, Ac. lineola, Bactrolithus delicatus, Cephalodidemnum carenon, C. pseudocarenon, Didemnobijugatus dichotomus, Disechinatus carinatus, Fusellinus insolitus, Paleodidemnum causianus, P. marjanensis, P. pseudoacutus, $P$. saudicus and Velasquezia minuta. 


\section{BIOSTRATIGRAPHY AND DISCUSSION}

Preservation of the calcareous nannofossils is moderate to good in the Tepal, Talu, and Yonjezar sections, whereas it is very poor for the Lavan section. No nannofossil was recorded from the basal sandstones of the Dalichai Formation. For this reason, the samples collected were not numbered. Based on the first and last appearance of the marker species and associated nannofossils, the CC1-CC5 biozones were identified according to Sissingh's (1977) nannofossil biozonation in the Tepal, Talu, Lavan, and Yonjezar sections as follows:

\section{Nannoconus steinmannii zone (CC1)}

This is the interval zone spanning from the first occurrence (FO) of Nannoconus steinmannii to the FO of Stradneria crenulata, and is latest Tithonian to Early Berriasian in age (Perch-Nielsen, 1985).

Re marks. - In the present study, according to Perch-Nielsen (1985), the FOs of Lithraphidites carniolensis and Nannoconus steinmannii subsp. steinmannii indicate the base of the Cretaceous as follows:

Tepal: Lithraphidites carniolensis and Nannoconus steinmannii subsp. steinmannii at $\sim 8 \mathrm{~m}$ from the base (sample no. 1 ).

Talu: Lithraphidites carniolensis at $5 \mathrm{~m}$ from the base (sample no. 1), and Nannoconus steinmannii subsp. steinmannii at $65 \mathrm{~m}$ from the base (sample no. 19).

Lavan: Lithraphidites carniolensis at $15 \mathrm{~m}$ from the base (sample no. 1).

Yonjezar: Lithraphidites carniolensis and Nannoconus steinmannii subsp. steinmannii at $10 \mathrm{~m}$ from the base (sample no. 1).

\section{Stradneria crenulata zone (CC2)}

This interval zone is from the FO of Stradneria crenulata to the FO of Calcicalathina oblongata, with an age of Late Berriasian to Early Valanginian (Perch-Nielsen, 1985).

R e m a r k s. - In the Geological Time Scale 2012, this biozone is of Early to Late Berriasian age (Ogg and Hinnov, 2012). Stradneria crenulata was not observed in the sections studied, but the FO of Calcicalathina oblongata is as follows:

Tepal: at $20 \mathrm{~m}$ from the base (sample no. 7).

Talu: at $\sim 68 \mathrm{~m}$ from the base (sample no. 21).

Lavan: was not observed.

Yonjezar: at $\sim 65 \mathrm{~m}$ from the base (sample no. 21)

Due to the lack of observations of Stradneria crenulata in Tepal, Talu, and Yonjezar sections, the two CC1, and CC2 zones are merged here; therefore, the first $20 \mathrm{~m}$ of the Tepal section, the first $68 \mathrm{~m}$ of the Talu section, and the first $65 \mathrm{~m}$ of the Yonjezar section are attributed to a CC1-CC2 zone and an Early Berriasian age is assigned to the base of the Dalichai Formation in these sections.

\section{Calcicalathina oblongata zone (CC3)}

This interval zone spans from the $\mathrm{FO}$ of Calcicalathina oblongata to the FO of Cretarhabdus loriei with an age of Late Valanginian (Perch-Nielsen, 1985).

R e m a r k s. - As shown in Ogg and Hinnov (2012), the FO of Calcicalathina oblongata demonstrates the base of the CC3 zone, indicating the beginning of the Valanginian. No species of Cretarhabdus loriei were observed in these 4 sections, but the first appearance of Calcicalathina oblongata, as noted above, represents the start of the CC3 zone and beginning of the Valanginian. In the Tepal section, due to the absence of calcareous nannofossils in the basal sandstone and the presence of Diadorhombus rectus (showing a Valanginian age) at $10 \mathrm{~m}$ from the base (sample no. 2), it is possible that Calcicalathina oblongata was present at lower levels. For this reason, the boundary between $\mathrm{CC} 1-\mathrm{CC} 2$ and $\mathrm{CC} 3$ is marked with a dotted line on the range chart of the Tepal section.

\section{Cretarhabdus loriei zone (CC4)}

This interval zone is defined from the FO of Cretarhabdus Ioriei to the LO of Speetonia colligata and its age is Late Valanginian to Early Hauterivian (Perch-Nielsen, 1985).

$\mathrm{R}$ e $\mathrm{m}$ a r k s. - Cretarhabdus loriei and Speetonia colligata were not found in any of the 4 sections. Applegate and Bergen (1988) inferred that the FO of Lithraphidites bollii divides this biozone into two subzones of CC4a and CC4b. Because of the lack of Speetonia colligata in the sections studied, the boundary between the CC3 and CC4 zones is not exactly clear, but the first appearance of Lithraphidites bollii at $\sim 127 \mathrm{~m}$ from the base (sample no. 41) of the Tepal section, at $116 \mathrm{~m}$ from the base (sample no. 47) of the Talu section, and at $\sim 123 \mathrm{~m}$ from the base (sample no. 34) of the Yonjezar section suggest the beginning of the Hauterivian Age for these parts of the sections.

\section{Lithraphidites bollii zone (CC5)}

This interval zone is from the LO of Speetonia colligata to the LO of Calcicalathina oblongata with an age of Late Hauterivian to Early Barremian (Perch-Nielsen, 1985).

R e m a rks. - As noted above, Speetonia colligate was not found in the sections studied whereas the LO of Calcicalathina oblongata was observed as below:

Tepal: at $\sim 151 \mathrm{~m}$ from the base (sample no. 52 ).

Talu: at $\sim 140 \mathrm{~m}$ from the base (sample no. 58).

Yonjezar: at $\sim 198 \mathrm{~m}$ from the base (sample no. 49).

This indicates an Early Barremian age for these parts of these sections.

Recording of species such as Assipetra terebrodentarius (sample no. 49 to 60), Nannoconus borealis (sample no. 52), Nannoconus abundans (sample no. 55), and Nannoconus wassallii (sample no. 55) in the Tepal section; Assipetra terebrodentarius (sample no. 53 to 61), and Nannoconus wassallii (sample no. 58) in the Talu section; Assipetra terebrodentarius (sample no. 48 and 49) and Nannoconus wassallii (sample no. 49 ) in the Yonjezar section, also indicates the CC5 zone in these parts of these 3 sections for the Dalichai Formation. Considering the lack of Speetonia colligata, the boundary between the CC4 and CC5 zones cannot be placed precisely.

According to the biozones identified, the age of the Tepal, Talu, and Yonjezar sections is from the Early Berriasian to the Early Barremian and age of the Lavan section, due to the presence of Lithraphidites carniolensis and Nannoconus circularis, is from the Early Berriasian to the Valanginian.

\section{PALAEOECOLOGY AND CORRELATION}

Among the nannofossils identified from the Dalichai Formation, Rhagodiscus asper, Watznaueria barnesiae, and Lithraphidites carniolensis are Lower Cretaceous cosmopolitan species; moreover, Nannoconus spp., Calcicalathina oblongata, Diadorhombus rectus, and Lithraphidites bollii were reported as Tethyan nannofossils (Mutterlose, 1992). 


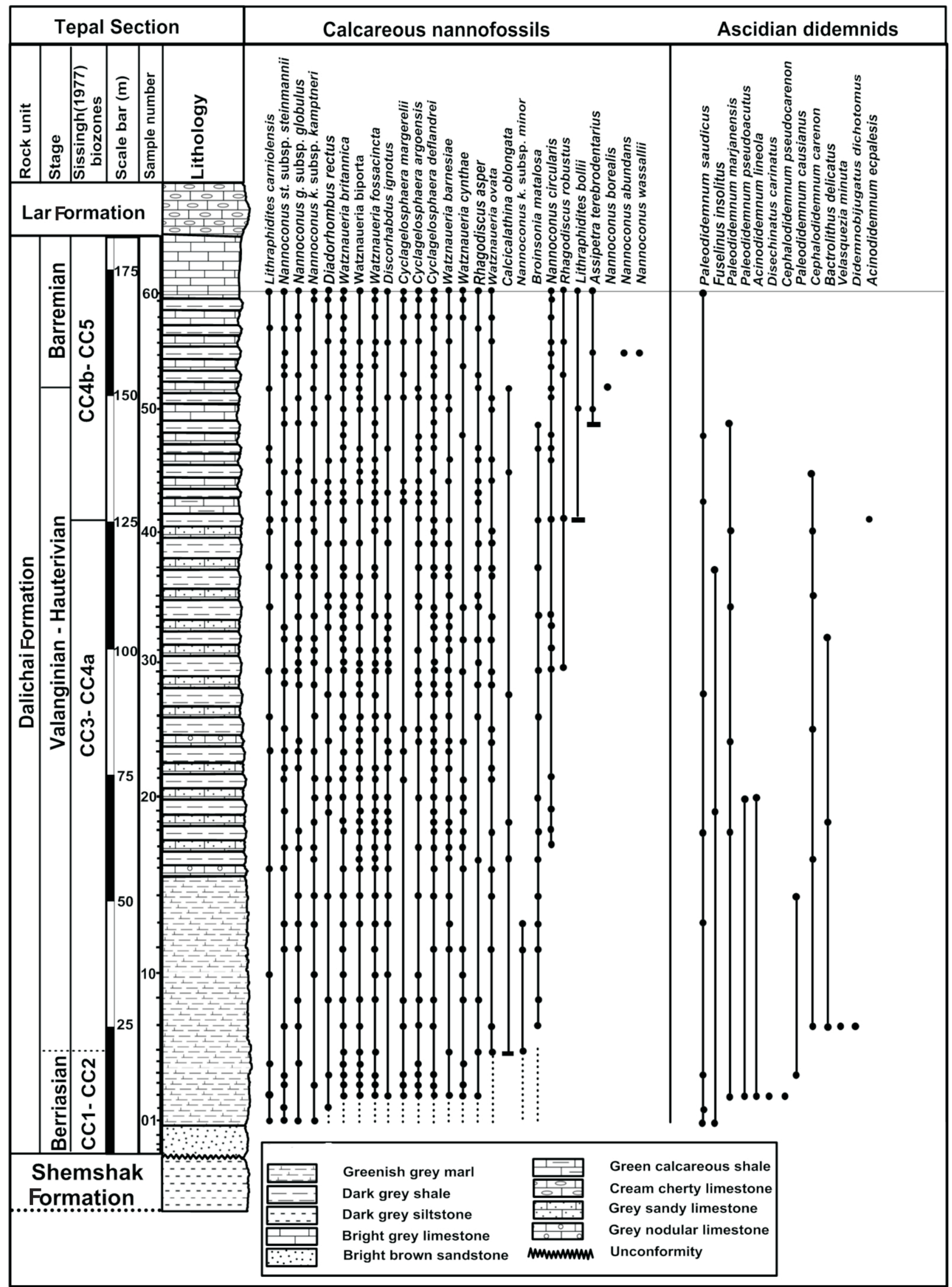

Fig. 2. Calcareous nannofossil biozonation of the Dalichai Formation 


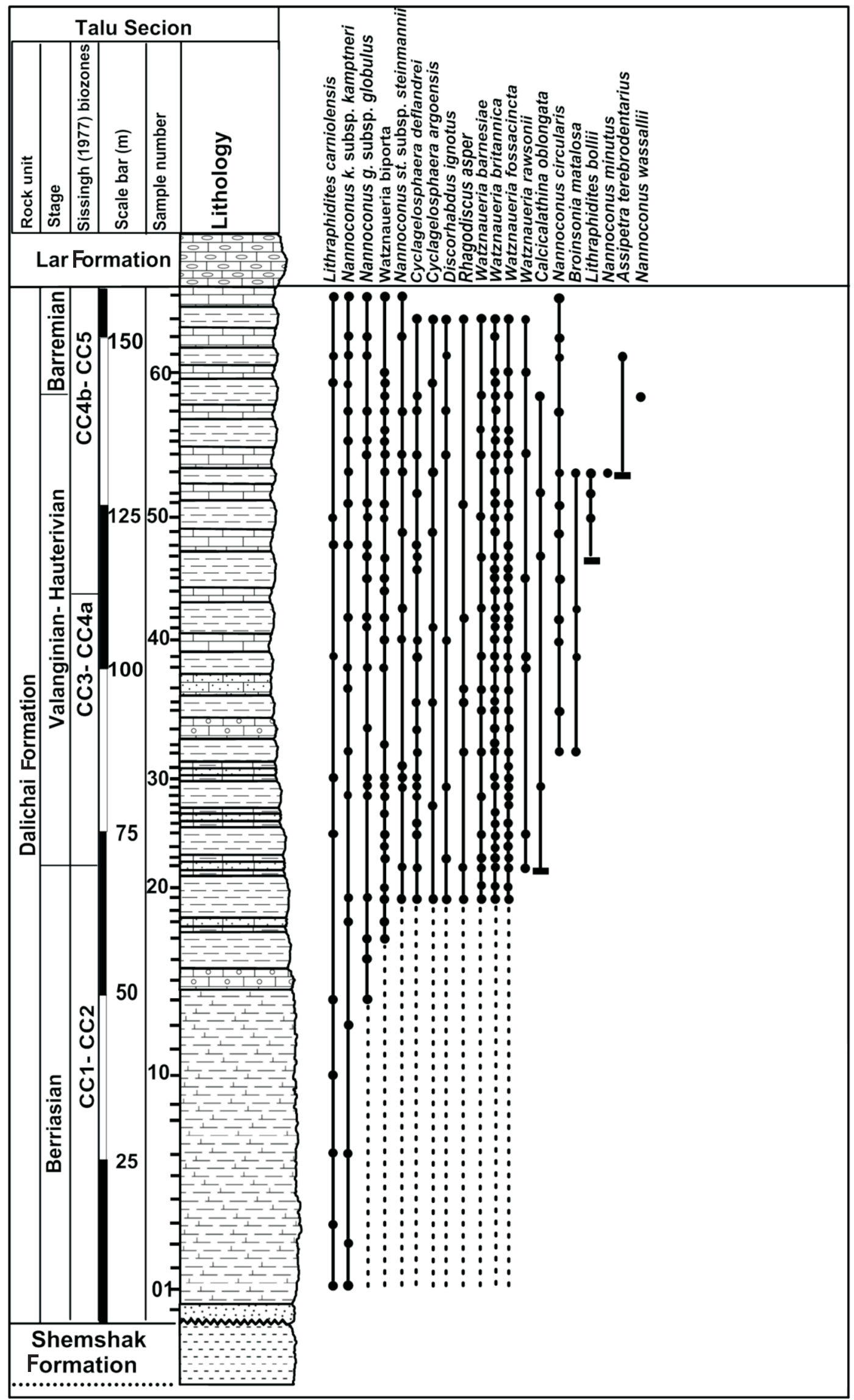

in the Tepal (Shiri, 2020) and Talu (Shiri, 2020) sections 


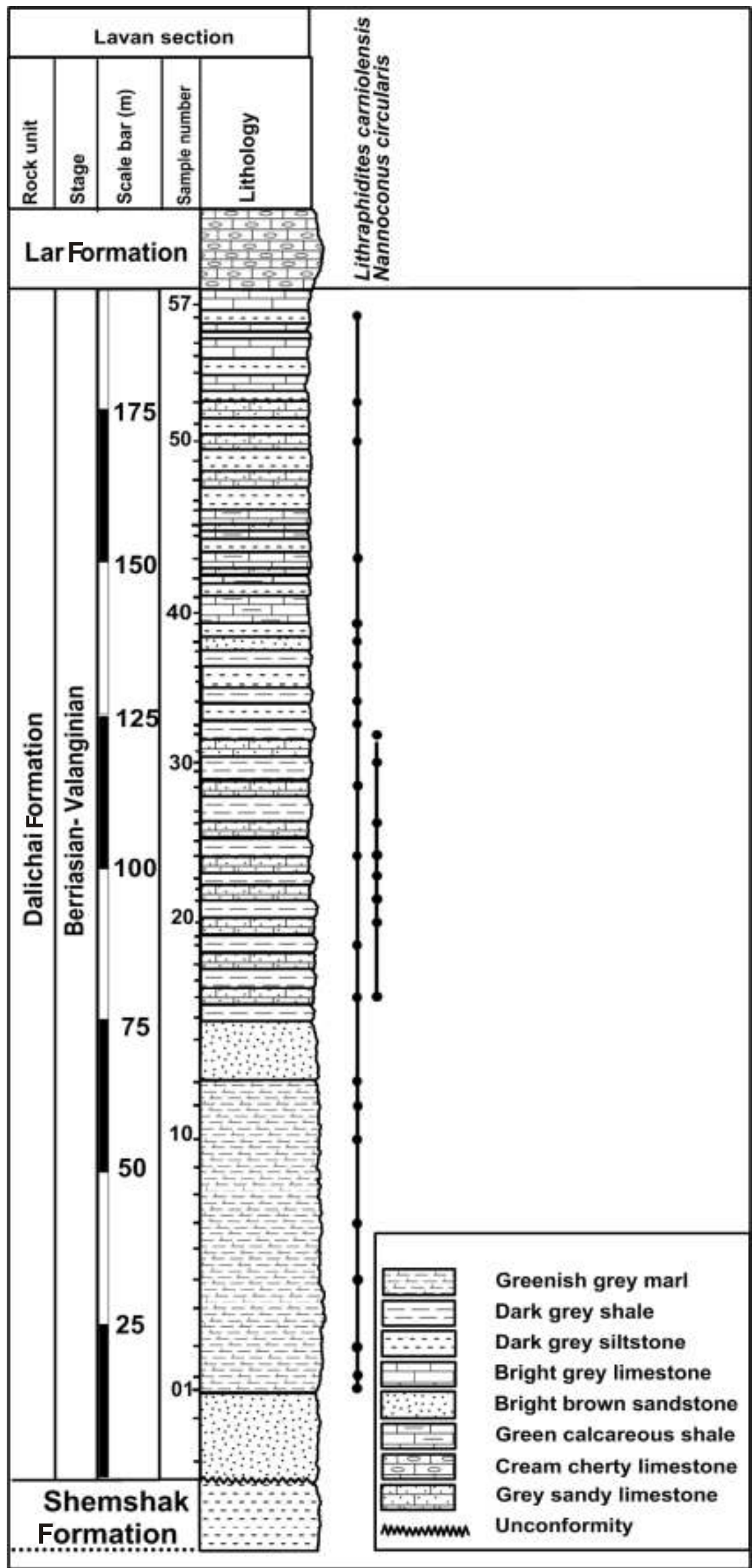

Fig. 3. Calcareous nannofossil biozonation of the Dalichai Formation 


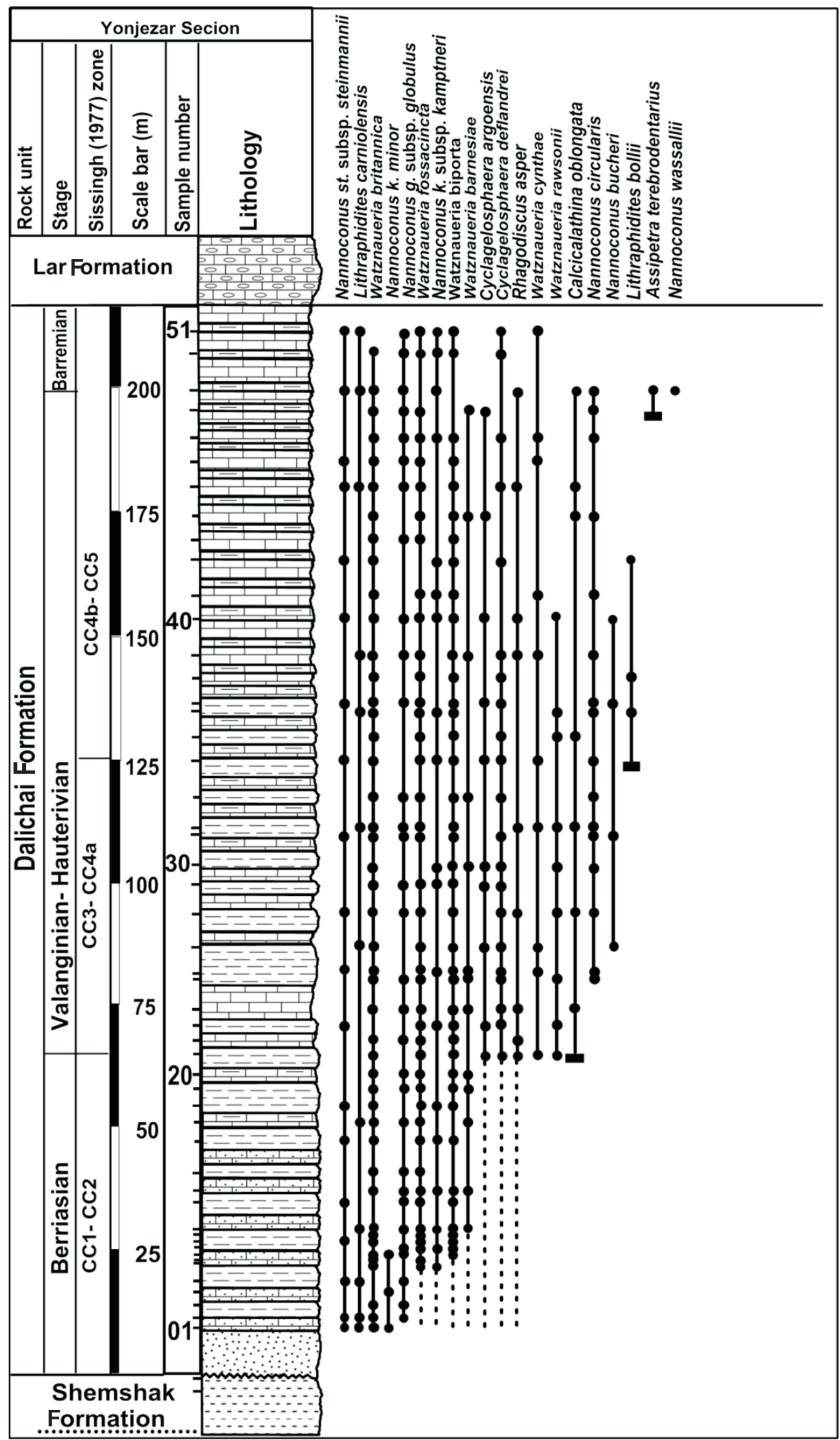

in the Lavan and Yonjezar sections 

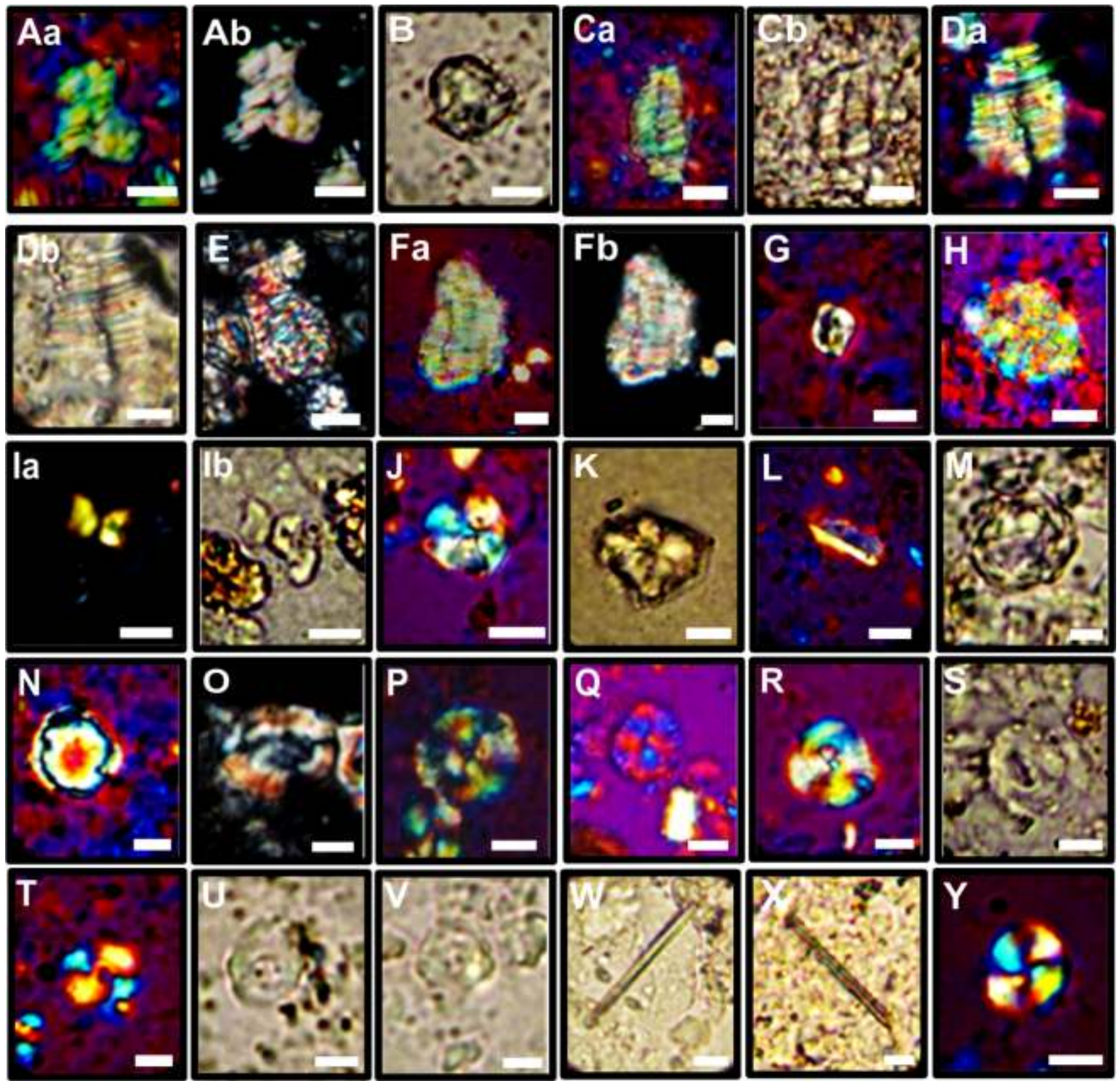

Fig. 4. Micrographs of calcareous nannofossils from the Tepal section (scale bars: $5 \mu \mathrm{m}$ )

Aa, b - Nannoconus borealis (no. 52); B - Nannoconus wassalli (no. 55); Ca, b, Da, b - Nannoconus steinmanii subsp. stainmanii (no. 29 , 32); E, Fa, b - Nannoconus kamptneri subsp. kamptneri (no. 1, 41); G - Diadorhombus rectus (no. 20); H - Calcicalathina oblongata (no. 49); la, b - Nannoconus abundans (no. 55); J, K - Assipetra terebradentarius (no. 55); L - Lithraphidites bollii (no. 50); M - Nannoconus globulus subsp. globulus (no. 37); N - Nannoconus circularis (no. 29); $\mathbf{0}$-Rhagodiscus robustus (no. 41); $\mathbf{P}$-Cyclagelosphaera argoensis (no. 42); Q - Discorhabdus ignotus (no. 31); R - Cyclagelosphaera deflanderi (no. 27); S - Watznaueria fossacincta (no. 22); T Watznaueria britannica (no. 17); U - Watznaueria cynthae (no. 29); V-Watznaueria biporta (no. 12); W, X - Lithraphidites carniolensis (no. 10, 29); Y - Watznaueria barnesiae (no. 50)

The nannofossils recorded are mainly Tethyan and cosmopolitan, but the presence of Boreal taxa is remarkable here. Nannoconus abundans and $N$. borealis are endemic species of the Boreal domain (Mutterlose, 1992) that are recorded here in the Tepal section. Vulc (2008) considered that the presence of Boreal nannofossils in the Tethyan Realm reflects their palaeo- biogeographical distribution and biotic shifts between Tethyan and Boreal waters, and the presence of nannofossils of both domains together can show a major exchange of water masses between these two realms. The presence of Nannoconus abundans and $N$. borealis in the Dalichai Formation may reflect 

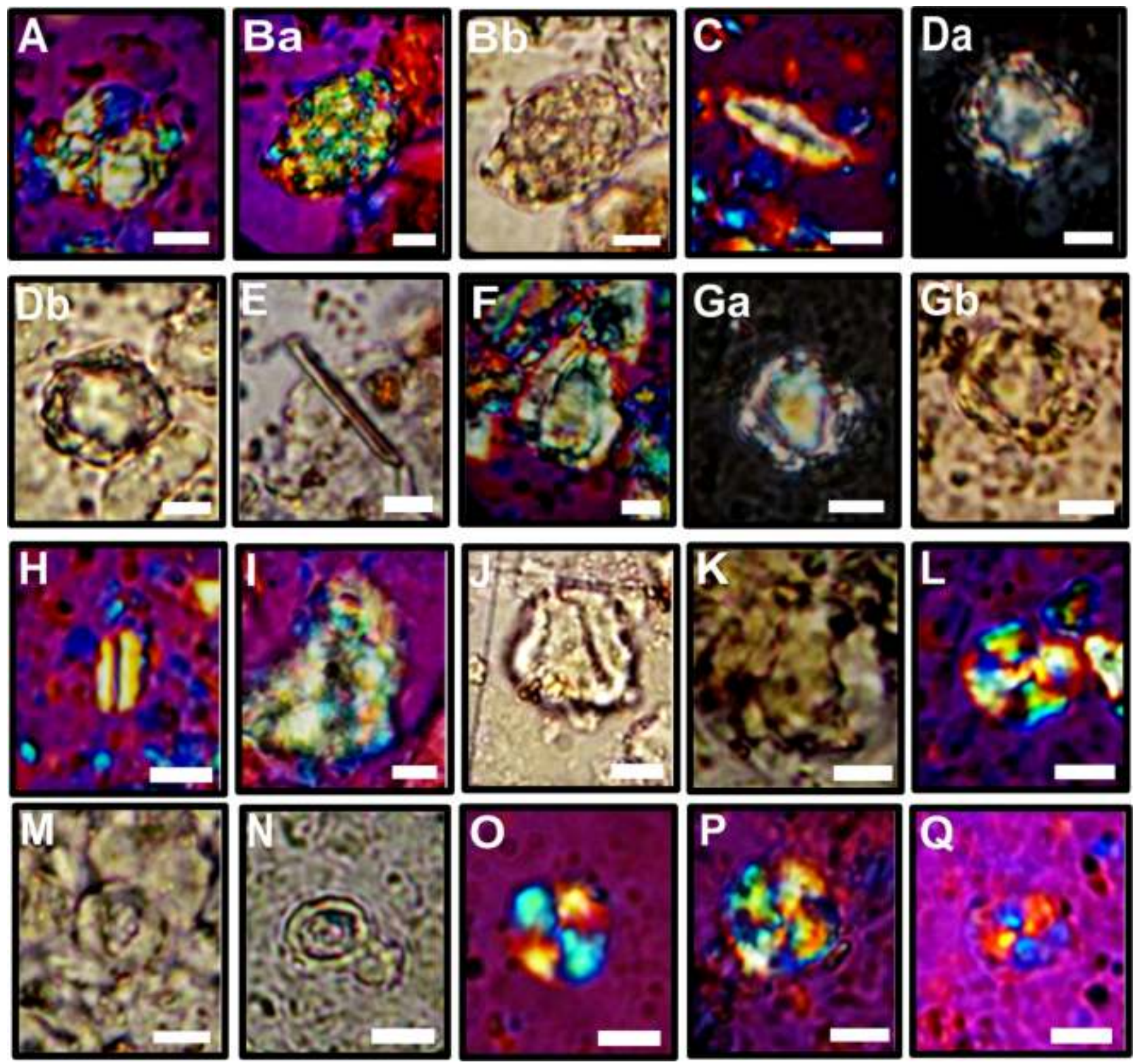

Fig. 5. Micrographs of calcareous nannofossils from the Talu section (scale bars: $5 \mu \mathrm{m}$ )

A - Assipetra terebrodentarius (no. 53); Ba, b - Calcicalathina oblongata (no. 21); C - Lithraphidites bollii (no. 52); Da, b - Nannoconus globulus subsp. globulus (no. 17); E - Lithraphidites carniolensis (no. 1); F - Nannoconus kamptneri subsp. kamptneri (no. 59); Ga, b Nannoconus circularis (no. 40); H - Nannoconus minutus (no. 53); I - Nannoconus steinmannii subsp. steinmannii (no. 40); J, K Nannoconus wassalli (no. 58); L - Watznaueria biporta (no. 42); $\mathbf{M}$ - Watznaueria rawsonii (no. 38); $\mathbf{N}-$ Rhagodiscus asper (no. 32); $\mathbf{O}-$ Watznaueria fossacincta (no. 34); P - Cyclagelosphaera deflanderi (no. 57); Q - Discorhabdus ignotus (no. 19)

a connection between the Boreal and Tethyan realms in the Lower Barremian.

The patterns of relative abundances for the most common species along with the nannofossil zonation are illustrated for the Tepal, Talu, and Yonjezar sections in Figures 8-10. These nannofossil assemblage patterns from the sections studied are used to interpret the palaeoecology of the Dalichai Formation in the Eastern and Central Alborz.

Thermophile warm-water taxa such as Nannoconus spp., Watznaueria spp., and Rhagodiscus asper (Erba, 1987;
Mutterlose, 1991; Erba, 1992), that dominated at low latitudes, are common in the Dalichai Formation, demonstrating relatively warm surface waters (Mutterlose et al., 2005). The Nannoconaceae appeared across the Jurassic-Cretaceous boundary for the first time (Bown et al., 2004). Nannoconus is a dominant sedimentary component in the Tithonian-Barremian (Busson and Nöel, 1991; Erba, 1994; Bersezio et al., 2002; Bornemann et al., 2003; Erba and Tremolada, 2004). It has been suggested that nannoconids were adapted for living in the lower photic zone (Erba, 1994; Herrle, 2003) ( 80-200 m), were most com- 

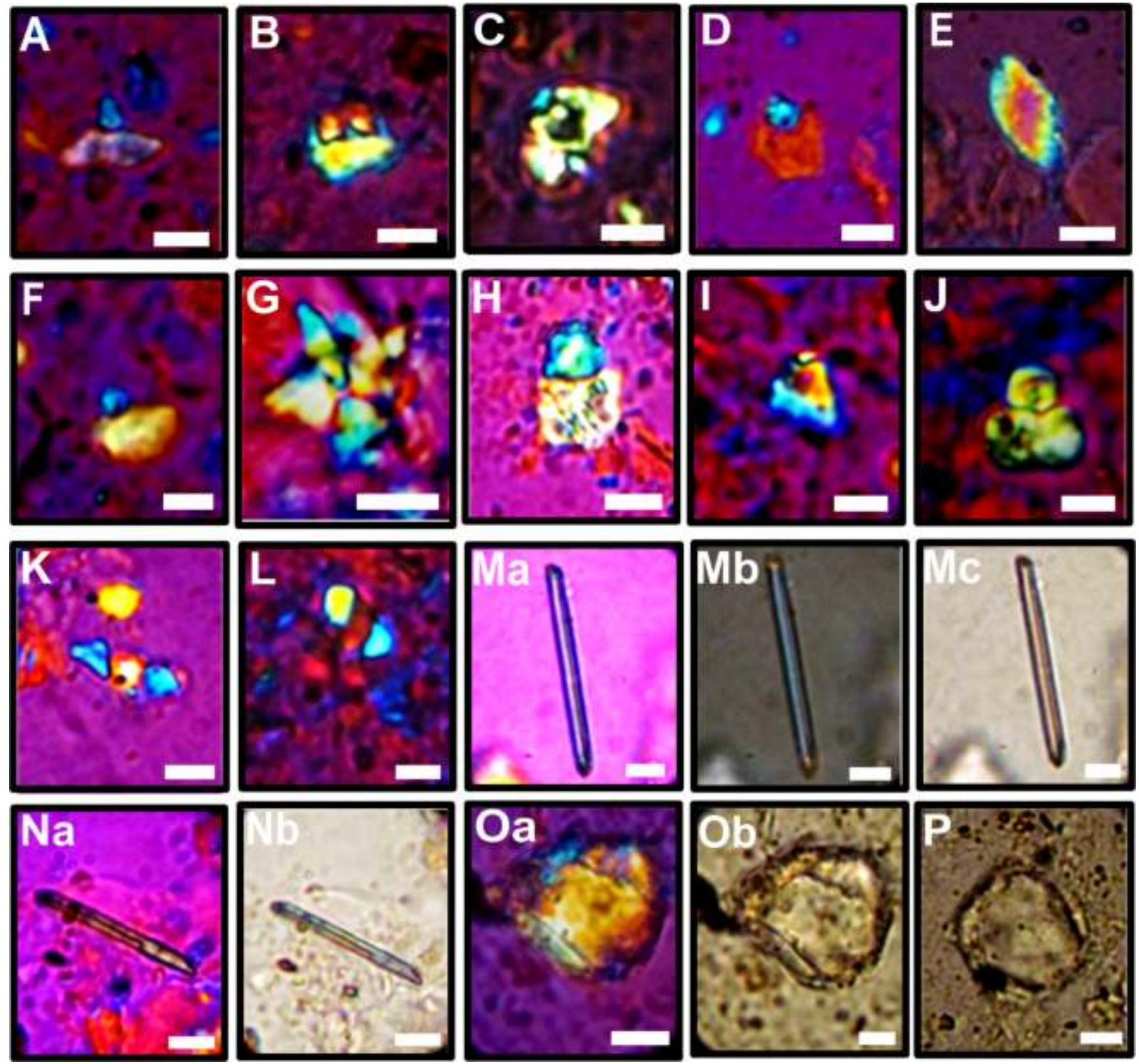

Fig. 6. Images of ascidian didemnids (A-L) from the Tepal section and micrographs of calcareous nannofossils (M-P) from the Lavan section (scale bars: $5 \mu \mathrm{m}$ )

A - Acinodidemnum lineola (no. 3); B - Disechinatus carinatus (no. 3); C - Acinodidemnum ecpalesis (no. 41 ); D - Cephalodidemnum pseudocarenon (no. 3); E - Fusellinus insolitus (no. 3); F - Paleodidemnum pseudoacutus (no. 3); G - Velasquezia minuta (no. 8); H Paleodidemnum causianus (no. 11); I - Paleodidemnum marjanensis (no. 3); $\mathbf{J}$ - Paleodidemnum saudicus (no. 1); K, L - Bactrolithus delicatus (no. 8, 32); Ma-c, Na, b - Lithraphidites carniolensis (no. 3, 10); Oa, b, P - Nannoconus circularis (no. 20, 26)

mon in low-turbulence environments, and had a k-mode of life (Mutterlose et al., 2005). Nannoconus spp. were influenced by the depth of the nutricline (Erba, 1994; Herrle, 2003). High abundances of Nannoconus spp. perhaps demonstrate high productivity in the lower photic zone (Mutterlose et al., 2005). Busson and Nöel (1991) assumed that nannoconids might have been calcitic dinoflagellate cysts, flourishing in clear waters and harmed by terrigenous influx. The abundance of nannoconids (Nannoconus spp.) has an inverse relationship with the abundance of other coccoliths, because nannoconids could poison surface waters and kill coccolithophorids, plank- tonic foraminifera, radiolarians, and sometimes benthic organisms (Erba, 1994). Watznaueria spp., with an r-selected life strategy (showing high turbulence and unstable conditions; Street and Bown, 2000; Lees et al., 2004; Mutterlose et al., 2005), are abundant in the Tepal, Talu, and Yonjezar sections, though their count reached zero at top of the Tepal and Talu sections, where nannoconids with a k-selected strategy (showing low turbulence and stable conditions; Mutterlose et al., 2005) became more abundant than at lower levels of these two sections. The absence of Watznaueria there could be due to the abundance and toxicity of nannoconids. Nannofossil assem- 

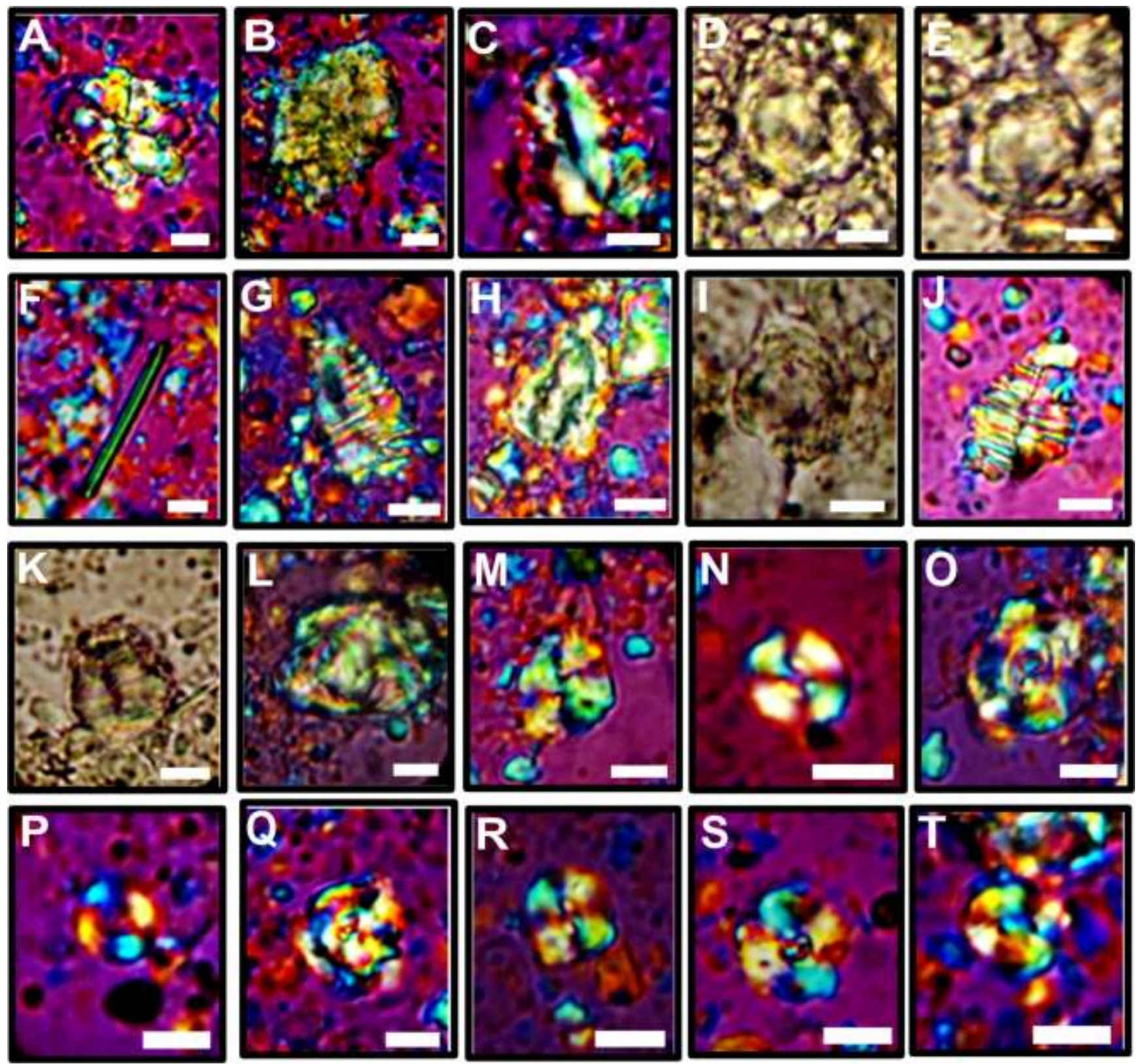

Fig. 7. Micrographs of calcareous nannofossils from the Yonjezar section (scale bars: $5 \mu \mathrm{m}$ )

A - Assipetra terebrodentarius (no. 48); B - Calcicalathina oblongata (no. 24); C - Lithraphidites bollii (no. 34); D, E - Nannoconus globulus subsp. globulus (no. 15, 22); F - Lithraphidites carniolensis (no. 1); G, H - Nannoconus kamptneri subsp. kamptneri (no. 34, 42); I Nannoconus circularis (no. 39); J, K - Nannoconus steinmannii subsp. steinmannii (no. 23, 31); L - Nannoconus wassalli (no. 49); $\mathbf{M}$ Watznaueria biporta (no. 23); N - Watznaueria barnesiae (no. 39); O - Cyclagelosphaera deflanderi (no. 28); P - Watznaueria rawsonii (no. 25); Q - Cyclagelosphaera argoensis (no. 27); R - Watznaueria fossacincta (no. 41); $\mathbf{S}$ - Watznaueria britannica (no. 44); T - Watznaueria cynthae (no. 32)

blages with high abundances of Watznaueria britannica indicate changing environmental conditions with high terrestrial fluxes (Kędzierski, 2012). An inverse relationship between the abundance of Nannoconus spp. and Watznaueria spp. is obvious in the relative abundance patterns of the Tepal, Talu, and Yonjezar sections.

Considering the opposing relationship between depth and abundance of Watznaueria barnesiae (Thierstein, 1976), and because of the decrease in the relative abundance of this species upwards in the Talu Section, it can be concluded that stratigraphically higher levels in the section reflect increased depth. The increase in the relative abundance of this species in the middle parts, reaching zero at the top of the Tepal section, indicates a decrease in depth represented by the middle parts of this section and an increase in depth by the uppermost parts, though demonstrating a trend of depth increase generally. As Watznaueria barnesiae was not observed in 20 fields of view, except for 2 samples, from the Yonjezar section, and was wholly absent from the Lavan section, certain conclusions cannot be drawn regarding changes in depth based on the relative abundance of this species in either section. 


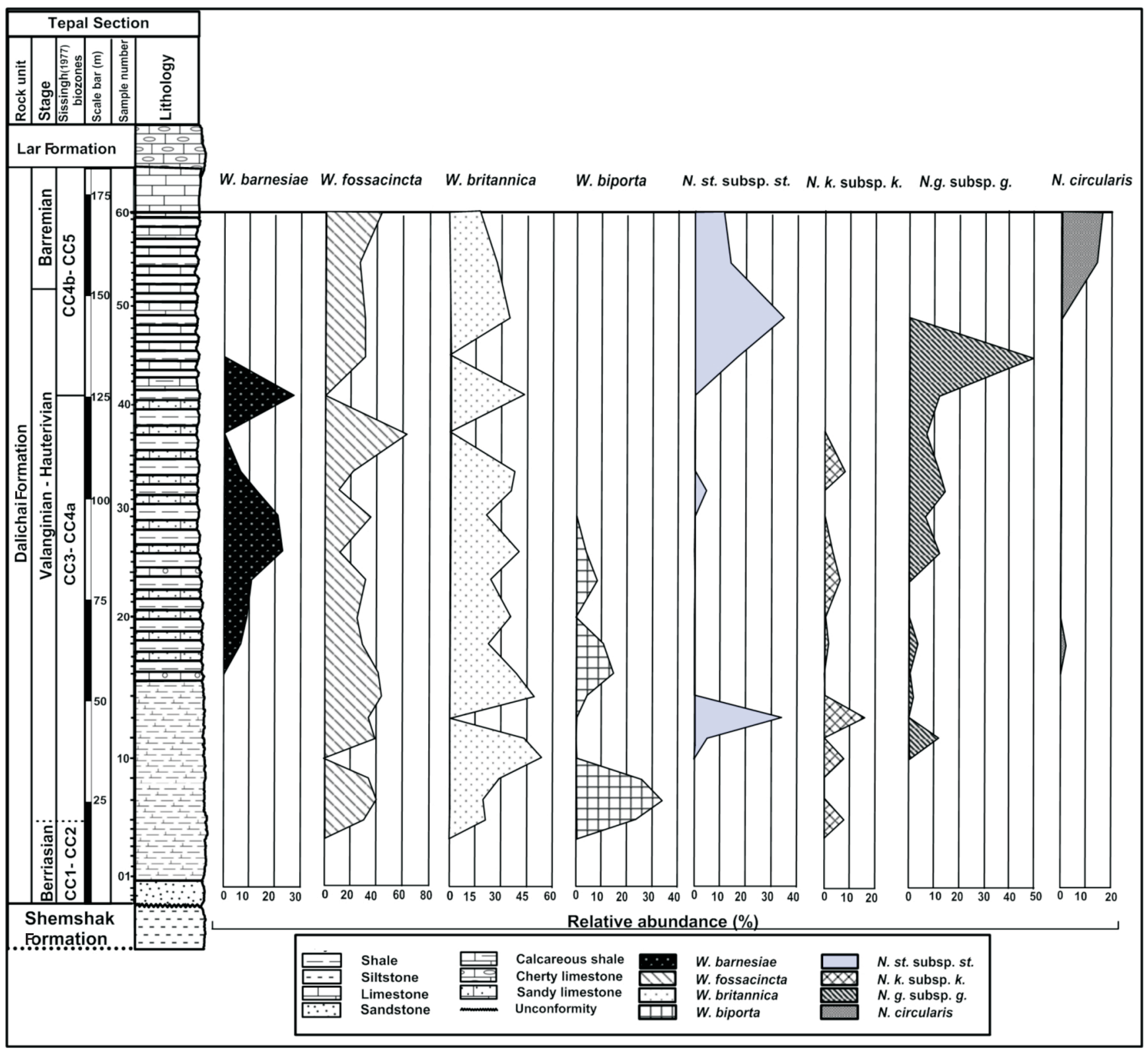

Fig. 8. Relative abundance of the most common species and nannofossil zonation in the Tepal section

Because nannoconids indicate high productivity and the lower photic zone (Erba, 1994; Herrle, 2003; Mutterlose et al., 2005), it can be said that a general increasing trend in the relative abundance of Nannoconus spp. (Nannoconus steinmannii subsp. steinmannii, N. kamptneri subsp. kamptneri, N. globulus subsp. globulus, N. circularis) shows a general increasing trend of depth and productivity in the Tepal section.

In the Talu section, an increasing trend of relative abundance of Nannoconus globulus subsp. globulus, N. kamptneri subsp. kamptneri, $N$. steinmannii subsp. steinmannii, and $N$. circularis from the middle to upper parts of the section, generally indicates an increase in-depth and productivity for this section.

In the Yonjezar section, Nannoconus steinmannii subsp. steinmannii, $N$. kamptneri subsp. kamptneri, and $N$. circularis have a general increasing trend toward the top, demonstrating also an increase in depth towards the top of this section; whereas, a temporary increase in-depth and productivity is signalled at lower levels of this section.

The decreasing trend of Watznaueria britannica in the Tepal section and its general decrease in the Talu section indicates a relatively increasing trend of stability and relaxation of environmental conditions for these 2 sections. In the Yonjezar section, the general decreasing trend of Watznaueria britannica also implies a decreasing trend of instability in the sedimentary basin.

Pittet and Mattioli (2002) concluded that W. britannica was more abundant in low-to-high mesotrophic conditions, whereas W. barnesiae was more abundant in oligotrophic conditions (Kędzierski, 2012), therefore, shifting from low-to-high mesotrophic conditions (due to the dominance of $W$. britannica) to oligotrophic conditions (due to a dominance of $W$. barnesiae 


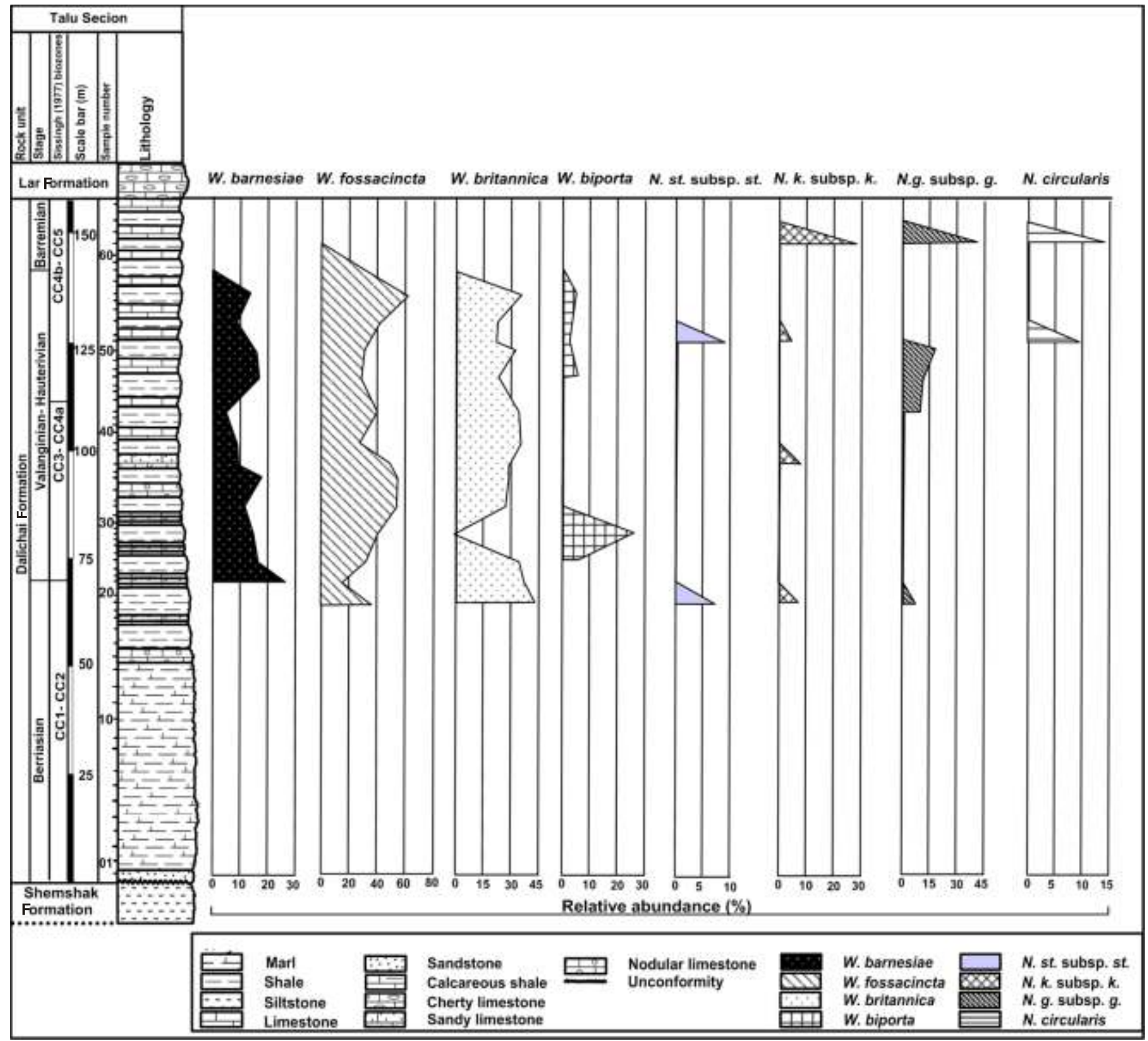

Fig. 9. Relative abundance of the most common species and nannofossil zonation in the Talu section (Shiri, 2020)

and nannoconids) was also suggested towards the top in the Tepal, Talu, and Yonjezar sections.

As noted above, among the 4 sections studied of the Dalichai Formation, ascidian spicules were observed only in the Tepal section. Ascidians as filter-feeding tunicates (Varol and Houghton, 1996), and important members of marine benthic colonies in shelf seas (Varol and Houghton, 1996), are distributed worldwide (Plough, 1978). They are depth-sensitive and are usually found in shallow waters (0-50 m) (Varol and Houghton, 1996). Strata containing abundant ascidians typically represent shallow-marine sedimentary environments (Varol, 2006). The presence of ascidian spicules in turbiditic deposits adjacent to carbonate-rich shelf environments demonstrates their resistance to erosion, transport, and deposition in warm waters (Beall and Fischer, 1963; Wei, 1993; Varol and Houghton, 1996). Observation of spicules in deposits indicates high sedimentation rates (Hought- on and Jenkins, 1988; Varol and Houghton, 1996). Due to the presence of this group of calcareous nannofossils in the Tepal section, it seems that the Dalichai Formation was less deep in this section than in the others.

To have a palaeoecological and palaeogeographical view of the Dalichai Formation, the Tepal, Talu, and Yonjezar sections were correlated (Fig. 11). Due to the lack of zonal index nannofossils in the Lavan section, this section was excluded from this this correlation. Calcareous nannofossils identified in the Tepal, Talu and Yonjezar sections show that these successions are coeval, corresponding to the CC1-CC5 biozones of Sissingh's (1977) zonation, with an age of Berriasian-Early Barremian. Despite the coincidence of these 3 sections, they show lateral facies changes, largely reflecting varying local depositional environments of the Dalichai Formation, starting with the sandstone at the base of these sections. 


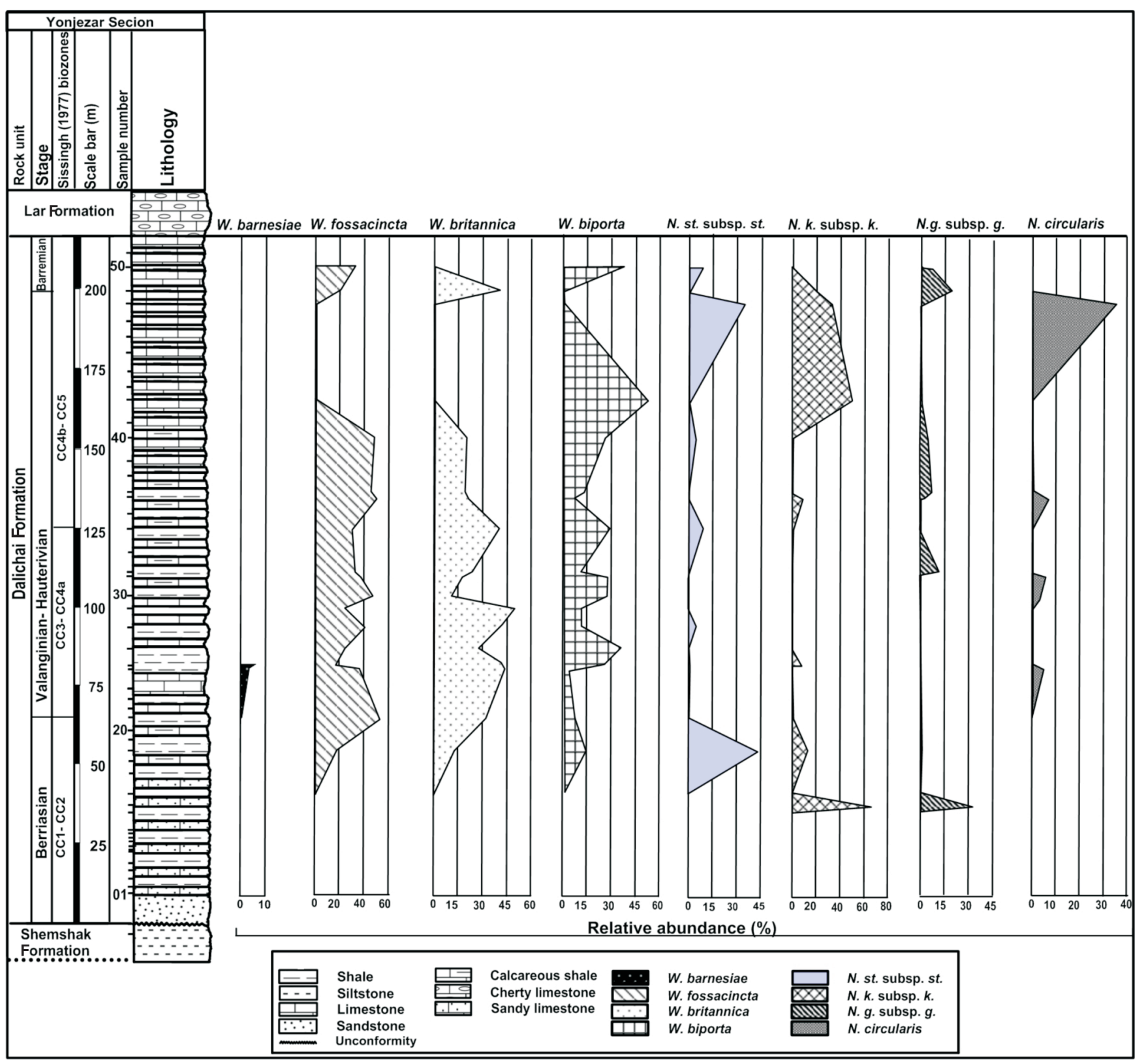

Fig. 10. Relative abundance of the most common species and nannofossil zonation in the Yonjezar section

The lateral correlation of these 3 sections shows that, generally, the relative abundance of nannoconids has increased from the Tepal to the Yonjezar section, from east to west, the relative abundance of nannoconids in Talu section being between the values of the Tepal and Yonjezar sections (Appendices 1-3). Given the relative abundance distribution patterns of nannoconids together with the lithological evidence and considering the presence of ascidian spicules in the Tepal section only, it appears that the source of sedimentary materials was close to the Tepal section (in the east), and an increase in sedimentary basin depth is deduced for the Dalichai Formation from east to west. This conclusion is consistent with the view that nannoconids would have preferred clear waters, high levels of suspended sediment being unsuitable for them (Busson and Nöel, 1991; Erba, 1994). This interpretation also is compatible with the inferred shallow-marine sedimentary setting of ascidian spicules (Varol, 2006), indicating high sedimentation rates (Houghton and Jenkins, 1988; Varol and Houghton, 1996), and
Table 2

Number of nannofossils identified from the Dalichai Formation

\begin{tabular}{|l|c|c|c|c|}
\hline \multirow{2}{*}{ Section name } & \multicolumn{2}{|c|}{$\begin{array}{c}\text { Calcareous } \\
\text { nannofossils }\end{array}$} & \multicolumn{2}{c|}{ Ascidian Didemnids } \\
\cline { 2 - 5 } & Genera & Species & Genera & Species \\
\hline Tepal & 10 & 26 & 8 & 13 \\
\hline Talu & 9 & 20 & - & - \\
\hline Lavan & 2 & 2 & - & - \\
\hline Yonjezar & 7 & 20 & - & - \\
\hline
\end{tabular}

the probability of their presence in turbiditic sediments (Beall and Fischer, 1963; Wei, 1993; Varol and Houghton, 1996). In addition, as variations in biozone thickness are indicators of sedimentation rates (e.g., Kastens et al., 1987: p. 424; Reda et 


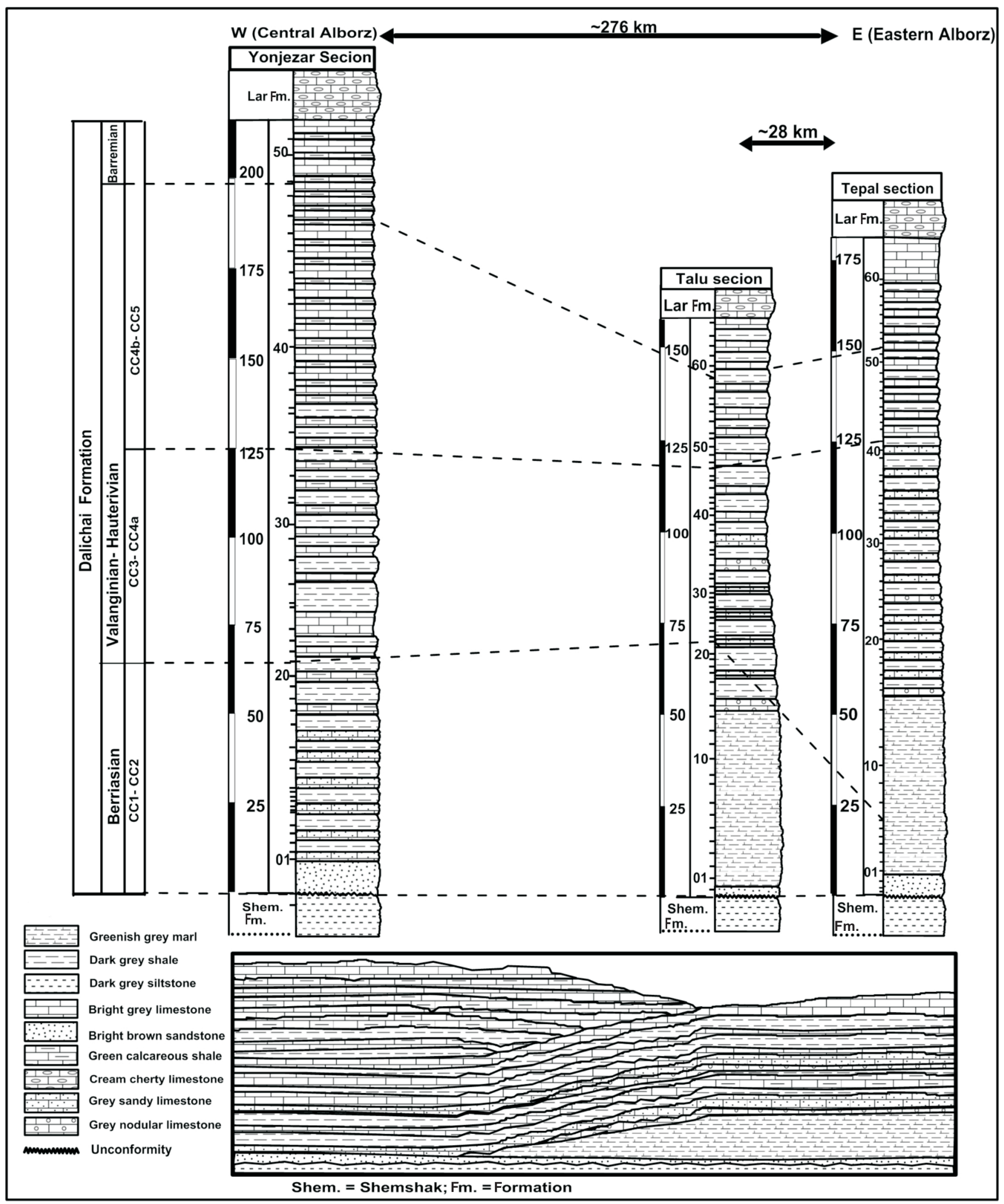

Fig. 11. Correlation of the Tepal, Talu, and Yonjezar sections based on the calcareous nannofossil biostratigraphy, shown in a schematic east-west transect across the Dalichai Formation Basin 
al., 2019), the small thickness of the CC1-CC2 zone indicates a low sedimentation rate for this biozone, while the large thickness of the CC3-CC4a zone demonstrates a high sedimentation rate for this biozone in the Tepal section; for comparison, there is no obvious change in these biozones in the Talu and Yonjezar sections. The thickness of the CC4b-CC5 biozone is greater in the Yonjezar section than in the Tepal and Talu sections, showing a high depositional rate for this biozone in the Yonjezar section that may be due to turbiditic input to the Yonjezar location during the time represented by this biozone.

The available evidence - lateral and vertical variations in the relative abundances of nannofossils, the presence of ascidian spicules in the Tepal section only, the thickness changes of the biozones, and the sedimentary model obtained from the Dalichai sedimentary basin - suggests that the Dalichai Formation represents a shallower depth and higher sedimentation rate in the Tepal section. Also, increase in the relative abundance of Nannoconus spp. in the Yonjezar section compared to the Tepal and Talu sections suggests an increase in oligotrophic conditions, along with low stress and little turbulence, in the basin from east (eastern Alborz) to west (central Alborz).

\section{CONCLUSIONS}

Calcareous nannofossils from the Dalichai Formation from 4 sections (Tepal, Talu, and Lavan sections in the eastern Alborz and the Yonjezar section in the central Alborz) include 42 species belonging to 18 genera of calcareous nannofossils from al four sections, together with 13 species belonging to 8 genera of ascidian didemnids from the Tepal section only. The calcareous nannofossils identified indicate that these successions are coeval, corresponding to the CC1-CC5 biozones of Sissingh's (1977) zonation with an age of Berriasian-Early Barremian. Geographically, the Dalichai Basin was located at low latitudes of the Tethyan realm with warm surface water. Palaeoecological interpretation of the Dalichai Formation in the Tepal, Talu, and Yonjezar sections demonstrates an increase in depth and productivity and a shift from r-selected to k-selected strategies (unstable to stable conditins) with a high relative abundance of Nannoconus spp., as well as a change from low-to-high mesotrophic to oligotrophic towards the top of the Tepal, Talu, and Yonjezar sections. Correlation of these 3 sections indicates that: the source of sedimentary materials was near to the Tepal section (in the east); there was an increase in the depth of sedimentary basin of the Dalichai Formation from east to west; there was an increase in oligotrophic conditions and also a decrease in stress and turbulence of the basin from east (Eastern Alborz) to west (Central Alborz) for the Dalichai Formation. In general, the nannofossils recorded from the Dalichai Formation are mainly Tethyan and cosmopolitan, but the presence of Boreal taxa (Nannoconus abundans and Nannoconus borealis) is remarkable and may reflect a connection between the Boreal and Tethyan realms in the Early Barremian.

Acknowledgements. We thank the journal reviewers, M. Kędzierski and M. Anvar Moheghy, their helpful comments and suggestions.

\section{REFERENCES}

Aghanabati, A., 2004. Geology of Iran. Ministry of Industry and Mines, Geological Survey of Iran.

Applegate, J.L., Bergen, J.A., 1988. Cretaceous calcareous nannofossil biostratigraphy of sediments recovered from the Galicia Margin, ODP Leg 103. Proceedings of the Ocean Drilling Program, Scientific Results, 103: 293-348.

Barsan Najjar, M., Hadavi, F., Notghimoghadam, M., 2016 Biostratigraphy of the Dalichai Formation based on calcareous nannofossils in Ferizi section (in Persian); A. Ghaderi (ed). In: Collection of articles of the 10th meeting of Iranian Paleontological Society, 159

Bornemann, A., Aschwer, U., Mutterlose, J., 2003. The impact of calcareous nannofossils on the pelagic carbonate accumulation across the Jurassic/Cretaceous boundary. Palaeogeography, Palaeoclimatology, Palaeoecology, 199: 187-228.

Bown, P.R., Young, J.R., 1998. Techniques. In: Calcareous Nannofossil Biostratigraphy (ed. P.R. Bown): 132-199. Chapman and Hall, London.

Bown, P.R., Lees, J.A., Young, J.R., 2004. Calcareous nannoplankton evolution and diversity through time. In: Coccolithophores. From Molecular Processes to Global Impact (eds. H.R. Thierstein and J.R. Young): 481-508. Springer, Berlin.

Beall, A., Fischer, A.G., 1963. Sedimentology. Initial Reports of the Deep Sea Drilling Program, 1: 521-593.

Bersezio, R., Erba, E., Gorza, M., Riva, A., 2002. Berriasian-Aptian black shales of the Maiolica formation (Lombardian Basin, Southern Alps, Northern Italy): local to global events. Palaeogeography, Palaeoclimatology, Palaeoecology, 180 253-275.
Busson, G., Nöel, D., 1991. Les nannoconidés indicateurs environmentaux des océans et mers épicontinentales du Jurassique terminal et du Crétacé inférieur. Oceanologica Acta, 14 333-356.

Dehbozorgi, A., Sajadi, F., Hashemi, H., 2013. Middle Jurassic palynomorphs of the Dalichai Formation, central Alborz Ranges, northeastern Iran: paleoecological inferences (in Persian). Earth Sciences, 56: 2107-2115.

Dehbozorgi, A., Hashemi-Yazdi, F., Sajjadi Hazaveh, F., 2018. Palynostratigraphy and paleoenvironmental interpretation of the Dalichai Formation, at the Pol Dokhtar stratigraphic section, central Alborz (in Persian). Applied Sedimentology, 6: 35-48.

Erba, E., 1987. Mid-Cretaceous cyclic pelagic facies from the Umbrian-Marchean Basin: what do calcareous nannofossils suggest? International Nannoplankton Association Newsletters, 9: $52-53$.

Erba, E., 1992. Middle Cretaceous calcareous nannofossils from the Western Pacific (Leg 129): evidence for palaeoequatorial crossings. Proceedings of the Ocean Drilling Program, Scientific Results, 129: 189-201.

Erba, E., 1994. Nannofossils and superplumes: the early Aptian "nannoconid crisis". Paleoceanography and Paleoclimatology, 9: 483-501.

Erba, E., Tremolada, F., 2004. Nannofossil carbonate fluxes during the early Cretaceous: phytoplankton response to nutrification episodes, atmospheric $\mathrm{CO}_{2}$ and anoxia. Paleoceanography, 19: $1-18$.

Ghasemi-Nejad, E., Sabbaghiyan, H., Mosaddegh, H., 2012 Paleobiogeographic implications of late Bajocian-late Callovian (Middle Jurassic) dinoflagellate cysts from the Central Alborz 
Mountain, northern Iran. Journal of Asian Earth Sciences, 43: $1-10$.

Hadavi, F., Moheghy, M.A., Ghadamgahi, M., 2015. Nannostratigraphy of Dalichai Formation in Naviya section of Kopet-Dagh. Journal of Nannoplankton Research, 35: 42.

Hashemi Yazdi, F., Sajjadi, F., Hashemi, H., 2018. Palynostratigraphy of the Middle Jurassic strata of central and eastern Alborz (in Persian). Journal of Stratigraphy and Sedimentology Researches, 34: 21-36.

Herrle, J.O., 2003. Reconstructing nutricline dynamics of mid-Cretaceous oceans: evidence from calcareous nannofossils from the Niveau Paquier black shale (SE France). Marine Micropaleontology, 47: 307-321.

Houghton, S.D., Jenkins, D.G., 1988. Subtropical microfossil indicators from the Pliocene Celtic Sea. Marine Geology, 79: $119-126$.

Jafari, A., 1989. Geology of Iran, mountains and mountain names of Iran (in Persian). Gitashenasi Geographical and Cartographic Institute.

Kastens, K.A., Mascle, J., Auroux, C., Bonatti, E., Broglia, C., Channell, J., Curzi, P., Emeis, K.Ch., Glaşon, G., Hasegawa, Sh., Hieke, W., McCoy, F., McKenzie, J., Mascle, G., Mendelson, J., Müller, C., Réhault, J.P., Robertson, A., Sartori, R., Sprovieri, R., Torii, M., 1987. Proceedings of the Ocean Drilling Program, Initial Reports, Part A, 107.

Kędzierski, M., 2012. Calcareous nannofossils from the Bathonian (Middle Jurassic) ore-bearing clays at Gnaszyn as palaeoenvironmental indicator, Kraków-Silesia Homocline, Poland. Acta Geologica Polonica, 62: 421-437.

Lees, J.A., Bown, P.R., Young, J.R., Riding, J.B., 2004. Evidence for annual records of phytoplankton productivity in the Kimmeridge Clay Formation coccolith stone bands (Upper Jurassic, Dorset, UK). Marine Micropaleontology, 52: 29-49.

Mafi, A., Ghasemi-Nejad, E., Ashouri, A., Vahidi-Nia, M., 2014 Dinoflagellate cysts from the Upper Bajocian-Lower Oxfordian of the Dalichai Formation in Binalud Mountains (NE Iran): their biostratigraphical and biogeographical significance. Arabian Journal of Geosciences, 7: 3683-3692.

Majidifard, M.R., 2004. Biostratigraphy, lithostratigraphy, ammonite taxonomy and microfacies analysis of the Middle and Upper Jurassic of northeastern Iran. Ph.D. thesis, der Bayerischen Julius Maximilians-Universität Würzburg, Würzburg.

Mutterlose, J., 1991. Das Verteilungs- und Migrationsmuster des kalkigen Nannoplanktons in der borealen Unter-Kreide (Valangin-Apt) NW-Deutschlands. Palaeontographica (B), 221: 27-152.

Mutterlose, J., 1992. Biostratigraphy and palaeobiogeography of Early Cretaceous calcareous nannofossils. Cretaceous $\mathrm{Re}-$ search, 13: 167-189.

Mutterlose, J., Bornemann, A., Herrle, J.O., 2005. Mesozoic calcareous nannofossils - state of the art. Paläontologische Zeitschrift, 79: 113-133.

Ogg, J.G., Hinnov, L.A., 2012. Chapter 27, Cretaceous. In: The Geological Time Scale (eds. F.M. Gradstein, J.G. Ogg, M.D. Schmitz and G.M. Ogg): 793-853. Elsevier, Amsterdam.
Perch-Nielsen, K., 1985. Mesozoic calcareous nannofossils. In: Plankton Stratigraphy (eds. H.M. Bolli, J.B. Saunders and K. Perch-Nielsen): 329-426. Cambridge University Press.

Pittet, B., Mattioli, E., 2002. The carbonate signal and calcareous nannofossil distribution in an Upper Jurassic section (Balingen-Tieringen, Late Oxfordian, southern Germany). Palaeogeography, Palaeoclimatology, Palaeoecology, 179: 71-96.

Plough, H.H., 1978. Sea Squirts of the Atlantic Continental Shelf from Maine to Texas. Johns Hopkins University Press, Baltimore.

Reda, E.I., Gammal, M.H., Orabi, H., 2019. Coniacian-late Campanian Planktonic Events in the Duwi Formation, Red Sea Region, Egypt. Journal of Geology and Geophysics, 7: 2.

Seyed-Emami, K., Raoufian, A., Zand-Moghadam, H., 2018. Late Bajocian and Bathonian (Middle Jurassic) ammonites from the Dalichai Formation north of Damghan (Alborz, North Iran). Neues Jahrbuch für Geologie und Paläontologie Abhandlungen, 288: 183-203.

Shiri, R., 2020. Biostratigraphy of Dalichai formation based on calcareous nannofossils on Tepal, Talu and Lavan sections (Eastern Alborz basin). Ph.D. thesis, Ferdowsi University of Mashhad.

Sissingh, W., 1977. Biostratigraphy of Cretaceous calcareous nannoplankton. Geologie en Mijnbouw, 56: 37-65.

Street, C., Bown, P.R., 2000. Palaeobiogeography of Early Cretaceous (Berriasian-Barremian) calcareous nannoplankton. Marine Micropaleontology, 39: 265-291.

Thierstein, H.R., 1976. Mesozoic calcareous nannoplankton biostratigraphy of marine sediments. Marine Micropaleontology, $\mathbf{1}$ : 325-362.

Varol, O., 2006. Didemnid ascidian spicules from the Arabian Peninsula. Journal of Nannoplankton Research, 28: 35-55.

Varol, O., Houghton, S., 1996. A review and classification of fossil didemnid ascidian spicules. Journal of Micropalaeontology, 15: 135-149.

Vaziri, S.H., Majidifard, M.R., Jahani, D., Tahmasebi, M., 2011. Lithostratigraphy, Biostratigraphy and Sedimentary Environment of the Dalichai Formation in Ayeneh-Varzan Area, Central Alborz (in Persian). Geosciences, 19: 99-117.

Vulc, A.M., 2008. Lower Cretaceous calcareous nannofossils from the Southern Apuseni Mountains, Romania. Studia UBB Geologia, 53: 5-11.

Wei, W., 1993. Abundance patterns of Tunicate spicules at the Great Barrier Reef-Queensland Plateau Transect sites: implications for downslope transport and Early Pleistocene initiation of the Central Great Barrier Reef. Proceedings of the Ocean Drilling Program, Scientific Results, 133: 447 -453.

Wheeler, J.W., Sarjeant, W.A.S., 1990. Jurassic and Cretaceous palynomorphs from the Central Alborz Mountains, Iran: their significance in biostratigraphy and paleogeography. Modern Geology, 14: 267-353. 